\title{
“국제빈곤퇴치기여금” 도입 계획
}

박 강 호 / KOICA이사

\section{1. 도입배경}

2000년 유엔 정상회의에서 전세계의 지속가능 한 발전을 위한 천년개발선언이 채택되었고, 2001 년 유엔 정상회의에서는 동 선언의 실천을 위한 총 8개 항의 천년개발목표(Millenium Development Goals)가 채택되었다. 천년개발목표(MDGs)는 세 계 빈곤의 절반을 감축하고, 에이즈 - 말라리아 기아 등 전염병의 획기적 퇴치 등을 목표로 하고 있다. 그러나 2004년 이후 국제사회는 획기적 재 원의 조달이 없이는 천년개발목표 달성이 어렵다 는 것을 인식하고, 최빈개도국의 빈곤·질병퇴치 를 위한 혁신적 개발재원 발굴에 관한 논의를 본격 화하였다. 혁신적 개발재원 발굴 논의를 통해 국제 금융거래세, 항공권 연대기여금, 개도국에 대한 $\mathrm{IMF}$ 특별인출권(SDR) 추가배정, 무기거래세, 개 도국 출신 이주자의 송금비용 인하 등 다양한 방안 들이 제기되었다.
2005년 9월 유엔 천년개발목표 이행 점검 회의 에서는 항공권연대기여금을 포함한 혁신적 개발재 원 조달 방안 마련을 촉구하는 뉴욕 선언문이 채택 되었다. 2005년 9월 유엔 특별정상회의시 우리나 라는 국제사회의 빈곤과 기아문제해결을 위해 우 리의 책임과 역할을 하겠다는 약속을 하였으며, 이 의 일환으로 우리 정부는 2006년 초부터 국제사회 의 빈곤퇴치 지원을 위한 재원 마련 방안에 관해 관계부처간 협의를 진행하였다. 여러 방안 중 항공 권 연대기여금 도입 필요성에 모든 부처가 공감하 였으며, 구체적 도입방안을 검토해나갔다.

항공권 연대기여금(airline-ticket solidarity contribution)은 자국 출발 항공권에 소액의 기여 금을 부과, 동 기여금을 개발 원조 재원으로 활용 하는 혁신적 개발재원 조달 방안이다. 우리 정부는 국제사회에서 혁신적 개발재원의 일환으로 논의 되어온 항공권 연대기여금을 국제빈곤퇴치기여금 
으로 명명하기로 하였다. 2006년 3월 노무현 대통 령은 아프리카 순방기간 중 "아프리카 개발을 위 한 한국 이니셔티브”를 발표하였고, 동 내용 중에 우리 정부의 국제빈곤퇴치기여금 도입검토 계획을 포함시켰다.

기여금 부과의 대상이 국제선 항공권이 선택된 배경은 항공분야가 20 세기 이후 줄곧 이루어진 세 계화 과정에서 가장 큰 수혜자 중 하나였으며, 빈 곤퇴치를 통한 국제정세 안정이라는 범세계적 목 표에 가장 밀접한 연관성을 갖고 있기 때문이다. 개도국의 빈곤지속은 국제적인 정세 불안정의 주 된 요인으로 작용하여 왔으며, 항공여행 및 항공산 업은 국제적 테러의 주된 목표가 되어 왔다.

\section{2. 도입 필요성}

우리나라는 그동안 꾸준히 공적개발원조(ODA) 를 증대시켜왔으나, 아직도 우리 경제규모와 국제 적 위상에 비해 $\mathrm{ODA}$ 규모가 많이 미흡하다. 2005 년 국민소득을 기준으로한 우리나라의 경제력이 세계11위를 기록하였음에도 불구하고, 우리의 국 민소득(GNI) 대비 공적개발원조(ODA)규모는 선 진국 평균치인 $0.33 \%$ 에 크게 못미치는 $0.09 \%$ 에 불과한 실정이다. 국민 1 인당 연간 원조금액을 볼 때 선진국 평균은 121 불이나 우리의 경우 15 불에 불과하다. 이는 대외적으로 인색한 한국의 이미지 형성에 원인을 제공할 우려가 있으며, 특히 아프리 카 등 최빈개도국의 빈곤 및 질병 퇴치에 적극적인
관심을 보이고 있는 선진 원조공여국들과 비교하 여 우리나라가 인류공동의 과제 해결에 소극적이 라는 인상을 줄 수 있다. 정부예산에 의한 $\mathrm{ODA}$ 의 대폭적인 확대는 시간이 걸리고, 제약이 있으므로 전통적인 $\mathrm{ODA}$ 재원이 아닌 혁신적 개발재원의 도 입이 필요하다고 할 것이다. 따라서 우리나라의 $\mathrm{ODA}$ 확대와 인류공통과제 해결을 위한 우리의 적 극적인 의지 표명을 위해서 국제빈곤퇴치기여금의 도입은 필요하다.

부담금 부과가 항공수요를 저하시킬 것이라는 항공업계의 우려가 있으나, 이를 먼저 검토한 프랑 스 정부는 최근 유가상승 등의 제약요인에도 불구 하고 항공수요는 지속적인 증가추세를 보이고 있 고, 기여금의 액수가 항공권에 비해 극히 소액이어 서 부정적 영향은 미미한 것으로 분석하고 있다.

국제사회의 도입추세를 보면, 프랑스는 2006.7.1부터 항공세의 일부로 동 기여금(프랑스발 국내선 및 유럽지역 항공편은 1 유로, 국제선은 4 유 로 부과) 을 부과중이고, 영국, 칠레도 이미 조세형 식으로 부과하고 있다. 그밖에 브라질, 노르웨이, 룩셈부르크, 요르단, 콩고, 사이프러스, 코트디브와 르, 마다가스카르, 모리셔스, 니카라과 등 총 13 개 국이 항공권 연대기여금의 도입을 추진중이다.

\section{3. 시행방안}

우리나라를 출발하는 국제선 출국항공권 1 매당 
1 천원의 기여금을 부과할 계획이다. 내 · 외국인이 모두 적용되며(2세이하 아동 및 경유승객 제외), 부담금은 항공권 가격에 포함된다. 기여금은 우리 정부의 국제사회 빈곤과 질병퇴치를 위한 인도주 의적 사업에 한정하여 사용될 예정이다. 기여금은 우리의 외교적 효과를 최대한 달성할 수 있도록 집 행하되, 필요시 일부를 유엔 등 빈곤 · 질병 퇴치와 관련된 국제기구에 출연하는 방안도 고려할 수 있 다. 기여금으로 확보 가능한 재원은 연간 약150180억원 규모로 추정된다.

기여금의 공정한 운영을 기하기 위해 외교통상 부장관소속하에 국제빈곤퇴치기여금 운용심의위 원회를 설치하여 기여금의 운용에 관한 종합적인 사항을 심의하고, 징수된 기여금은 한국국제협력 단 $(\mathrm{KOICA})$ 의 별도 계정으로 관리 · 운용될 예정 이다.

현재 국제빈곤퇴치기여금도입을 위한 "한국국 제협력단법 일부 개정안”이 국무회의 의결을 거쳐 정기국회에 제출되어, 심의중에 있으며, 국회에서 통과되면 준비작업을 거쳐 2007년 중 시행될 수 있을 것으로 보인다. 국제빈곤퇴치기여금은 한국 국제협력단 개정법 시행후 5 년이 되는 날까지 부 과되며, 5년이후 계속실시 여부는 정부차원에서 검토하여 결정할 예정이다.

\section{UNITAID 참여}

2006년 9월 프랑스, 브라질, 칠레, 노르웨이, 영 국 등 항공권 연대기여금 제도를 도입하고 있는 국 가들은 천년 개발목표 $(M D G s)$ 에 명시된 $\mathrm{HIV} / \mathrm{AIDS}$, 말라리아, 결핵 등 3대 질병퇴치를 위 해 개도국에 양질의 의약품을 저가에 안정적으로 공급하는 것을 기본 목적으로 하는 국제의약품 구 매기금(UNITAID)를 창설 하였다. UNITAID는 $\mathrm{WHO}$, Global Fund, UNICEF 등 기존 국제기구 의 보완적 역할을 수행하게 되며, 의약품의 가격인 하, 약품 및 진료서비스의 공급확대를 추진하게 된 다. UNITAID의 운영 재원은 혁신적 개발재원, 특 히 항공권 연대기여금을 통해 전달하는 것을 원칙 으로 하되, 자발적인 기여금과 전통적인 $\mathrm{ODA}$ 재 원으로도 출연가능하다. 앞으로 모든 개도국은 $\mathrm{UNITAID}$ 를 통해 결정된 유리한 가격으로 의약품 구매가 가능해 질 것이다.

우리나라는 지난 9 월 유엔에서 개최된 UNITAID 창설 행사에서 UNITAID에 대한 참여 방침을 밝혔고, 11 월말 제네바에서 개최된 UNITAID 제2차 집행이사회에서 아시아 지역을 대표하는 이사국으로 참여하게 되었다. UNITAID 이사국은 우리나라 외에 프랑스, 브라질, 칠레, 노 르웨이, 브라질, $\mathrm{AU}, \mathrm{NGO}(2$ 석 $), \mathrm{WHO}$ 등 10 개국 으로 구성되어 있다. 우리나라는 국제빈곤퇴치기 여금을 통해 마련되는 재원 중 일부를 UNITAID 에 출연하는 방안을 추진 중이다. 우리나라는 
UNITAID에 참여함으로써 2006년 3월 "아프리카 개발을 위한 한국 이니셔티브”를 적극적으로 실현 하는 의지를 나타내게 되고, 유엔천년개발목표의 제1목표(절대빈곤 및 기아퇴치) 및 제 6 목표(주요질 병퇴치)에 적극 기여하는 인도주의적 국가 이미지 를 제고 할 수 있을 것이다.

\section{5. 맺음말}

지금까지 우리나라의 공적개발원조(ODA)는 정 부의 예산에 의해서만 실시되어 왔다. 그러나 금 번 국제빈곤퇴치기여금의 도입으로 국제사회의 빈곤퇴치를 위한 우리 국민의 직접적인 참여가 가 능해 졌으며, 우리 국민은 동 기여금에 참여함으
로써 성숙한 국제시민으로서 자긍심을 가질 수 있 을 것이다.

또한 우리 ODA규모의 상대적 열세에도 불구하 고, 새로운 재원발굴에 적극적이라는 이미지가 부 각되며, 2005년 9월 유엔총회에서 밝힌 빈곤과 기 아문제 해결을 위한 우리의 책임과 역할, 그리고 2006년 3월 "아프리카 개발을 위한" 이니셔티브 를 구체화하는 의의가 있다고 할 수 있다. 특히 국 제빈곤퇴치기여금은 국제사회에서 주로 유럽국가 들이 도입하고 있는데, 아시아에서는 유일하게 우 리나라가 선도그룹으로 참여함으로써 인도주의 국 가로서의 우리나라의 위상이 한층 제고될 것으로 보인다. 